\title{
日赤緯・均時差・地球太陽間距離の見積り \\ ESTIMATION OF SOLAR DECLINATION, EQUATION OF TIME, AND SUN-EARTH DISTANCE
}

\author{
永田忠彦*1, 藤野貴仁*2 \\ Tadahiko NAGATA and Takahito FUJINO
}

\begin{abstract}
In many cases, the position of the sun in the sky at a certain place on the earth at a certain time in a year is calculated by using data on the latitude of the place as well as the solar declination and the apparent solar time at the time. In order to obtain the apparent solar time in Japan, it is necessary to know Japan Standard Time and the equation of time at the time, and the longitude of the place. The intensity of solar radiation on the ground is affected by the distance between the sun and the earth. Among the above-mentioned quantities, as regards the three quantities of solar declination, equation of time, and sun-earth distance, it is not easy to know their sufficiently accurate values at a certain time in a year because they change depending on the time of year.
\end{abstract}

This paper presents a series of approximate equations for calculating these three quantities as functions of time passage after the vernal equinox or the perihelion.

Keywords : Solar declination, Equation of time, Sun-Earth distance, Vernal equinox, Perihelion 日赤緯, 均時差, 地球太陽間距離, 春分点, 近日点

1. はじめに

太陽位置を求める方法はいろいろあるが、検討地点の緯度、及ひ検 討時点における日赤緯 (太陽の赤緯)、その時点のその地点における 真太陽時の3つをもとにして太陽位置を計算することが多い。真太陽 時は、検討時点の日本標準時とその時点の均時差及び検討地点の経度 が分かれば求めることができる。また、地上で受ける日射の強さは、 年間を通じて変動する地球太陽間の距離に応じて変動する。こうした 事情から、今までにも、日赤緯・均時差・地球太陽間距離の見積りに 関する研究は少なからず行われている。1) 日赤緯と均時差、地球太陽 間距離は年間を通じて変動していて、しかも、理科年表 ${ }^{2)}$ にも示され ているように、これらの值は同じ月日であっても年が異なると僅かに 異なった值となっている。本研究は、同じ月日であっても年によって 僅かに異なり、しかも 1 日のうちでも僅か炕変動する上述の3つの量 を、春分からの又は地球が近日点を通過してからの経過時間の関数と して簡単に求める方法について検討したものである。
2. 太陽年と近点年について

本論文では、「春分点」という用語は本来の意味に加えて、「太陽が 黄道上の春分点を通過する時点」をも意味するものとし、「近日点」 は「地球が公転軌道上の近日点を通過する時点」をも意味するものと する。また、後述の「代用春分点」と「代用近日点」についても同様 である。

表 1 太陽年の長さ

\begin{tabular}{|c|c|c|c|c|c|c|}
\hline 年 & \multicolumn{4}{|c|}{ 春分点(理科年表) } & $\begin{array}{c}\text { 左の侹を } \\
\text { 㣂日で表示 }\end{array}$ & $\begin{array}{c}\text { 太晹年 (翌年の } \\
\text { 春分点までの時間) }\end{array}$ \\
\hline 1991 & 3月 & 21 日 & 3/時 & 2]分 & 80.12639 & 365.24028 \\
\hline 1992 & 3月 & 20日 & 8時 & 48分 & 80.36667 & 365.24514 \\
\hline 1993 & 3月 & 20:日 & 14時 & 41分 & 79.61181 & 365.24097 \\
\hline 1994 & 3月 & 20 日 & 20 時 & 28!分 & 79.85278 & 365.24028 \\
\hline 1995 & 3月 & 21 日 & 2/时 & 14 分 & 80.09306 & 365.24236 \\
\hline 1996 & 3 月 & 20 日 & 8時 & 3 分 & 80.33542 & 365.24444 \\
\hline 1997 & 3月 & 20 日 & 13/時 & 55 分 & 79.57986 & 365.25000 \\
\hline 1998 & 3月 & 20.日 & 19/時 & 55 分 & 79.82986 & 365.24375 \\
\hline 1999 & 3月 & 21 日 & 1)時 & 46分 & 80.07361 & 365.24236 \\
\hline 2000 & 3 F & 20 日 & 7時 & 35 分 & 80.31597 & 365.24722 \\
\hline 2001 & $3 E$ & 20日 & 13/時 & $31 /$ 分 & 79.56319 & \\
\hline & & & 平均 & & & 365.24368 \\
\hline
\end{tabular}

\footnotetext{
*1 駒沢女子大学 教授・工博

(福井大学 名誉教授)
}

*2 富士ソフト $\mathrm{ABC}$ 株 工修
Prof., Komazawa Women's University, Dr. Eng.

(Prof. Emeritus, Fukui University)

Fuji Soft ABC, Inc., M. Eng. 
太陽年とはある年の春分点から翌年の春分点までの時間をいうが、 1991 年から 2001 年の理科年表に揭載されている春分点から太陽年 を求めてみると、表 1 のうな值になり、通説となっている 365.24219 日と一致しない。

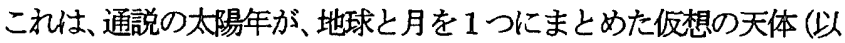
後「仮想地球」と呼ぶ。）がその質量中心にあって、その仮想地球が 太陽のまわりを楕円軌道を描いて公転しているとする理論から導き 出された仮想地球に関する太陽年であるからである。地球自体の実際 の公転軌道は滑らかな棈円形ではなく、月の引力のために幾分ふらつ いた軌道となっているからである。

一方、近点年とはある年の近日点から翌年の近日点までの時間をい う。ここで、近日点とは地球太陽間距離 $\rho$ が最小となる瞬間である。 理科年表には近日点が具体的に揭載されていないので、まず、理科年 表に載っている地球太陽間距離 $\rho$ 值を仮想地球に関するものと見 なして、仮想地球の近日点を算出することを試みた。近日点の近くで は単位時間当りの $\rho$ の変動が小さいので、補間で求められる「近日点」 には大きな誤差が含まれ易い。一方 $\rho=1(\mathrm{AU})$ となる時点の近くでは 単位時間当りの $\rho$ の変動が大きいので、補間で求められる「 $\rho=1$ となる時点」に含まれる誤差は小さくなる傾向がある。そこでまず 2001 年の地球太陽間距離 $\rho$ が 1 となる時点を探し、そこから近日点 を求めることにした。計算の結果、2001 年の $\rho=1$ となる 1 回目の 瞬間は、93.57493日（通日）となった。

また、ケプラーの法則、及び 1 近点年が 365.25964 日であること、

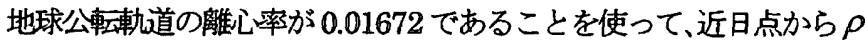
$=1$ となる瞬間までの経過時間を求めると 90.34293 日となることが 分かる。よって、2001年の近日点は、

$93.57493-90.34293=3.23200$ 日 (通日)

と求めることができる。

同様にして、1991〜2000 年の理科年表提載の值から各年の近日点 を上述の方法で求め、近点年を必要な倍数だけ加えることによって、 2001 年の近日点を推定すると、表 2 の值が得られる。

表 2 仮想地球の 2001 年の近日点

\begin{tabular}{|r|r|r|}
\hline & 理科年聚より \\
\hline 年年 & 严年の近日点 & 2001年の近日点 \\
\hline 1991 & 3.79388 & 3.39028 \\
\hline 1992 & 3.84918 & 3.18594 \\
\hline 1993 & 3.17753 & 3.25465 \\
\hline 1994 & 3.37799 & 3.19547 \\
\hline 1995 & 3.61447 & 3.17231 \\
\hline 1996 & 3.98880 & 3.28700 \\
\hline 1997 & 3.11613 & 3.15469 \\
\hline 1998 & 3.61151 & 3.39043 \\
\hline 1999 & 3.98112 & 3.50040 \\
\hline 2000 & 3.97191 & 3.23155 \\
\hline 2001 & & 3.23200 \\
\hline 平均 & & 3.27225 \\
\hline
\end{tabular}

推定のもととなる年（参考年）によって、2001 年の近日点の推定 値が幾分変わってしまうことが分かる。
表 2 に示す 1991 年から 2001 年までの各年の近日点から、近点年

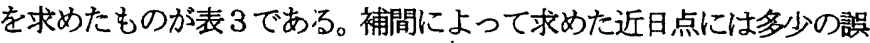
差があることは避けられ沈い゙、それにしても、近点年の長さが通説 の365.25964 日とはかなり異なる值となっている。

このように值が異なる理由は、太陽年の場合と同様に、通説の近点 年が、地球と月の質量中心にある仮想地球に関して求められているか らであり、地球自体の実際の公転軌道が滑らかな楕円形ではないから である。

表 3 近点年の长さ

\begin{tabular}{|r|r|r|}
\hline 年 & $\begin{array}{l}\text { 理科年表よりの } \\
\text { 近日点(通日) }\end{array}$ & $\begin{array}{l}\text { 近点年(翌年の } \\
\text { 近日点ま(゙の時間) }\end{array}$ \\
\hline 1991 & 3.79388 & 365.05530 \\
\hline 1992 & 3.84918 & 365.32835 \\
\hline 1999 & 3.17753 & 365.20046 \\
\hline 1994 & 3.37799 & 365.23647 \\
\hline 1995 & 3.61447 & 365.37433 \\
\hline 1996 & 3.98880 & 365.12733 \\
\hline 199 & 3.11613 & 365.49539 \\
\hline 1998 & 3.61151 & 365.36961 \\
\hline 1999 & 3.98112 & 364.99078 \\
\hline 2000 & 3.97191 & 365.26009 \\
\hline 200 & 3.23200 & \\
\hline & & 365.24381 \\
\hline
\end{tabular}

仮想地球は、地球加月の方向に約 0.00003 (AU) 離れているの で、実際の地球の日赤綪 $\delta, \rho$, 真太陽時と仮想地球のそれらとの 間には僅かな差異が生ずる。その差異は、月の公転軌道の方向を無視 して最大限に見㯺もっでも、 $\delta$ で $6^{\prime \prime} ， \rho$ で0.00003 (AU)，真太陽 時で $0.43 （ \mathrm{~s}$ ）の程度にしかならない。真太陽時の差異はそのまま均 時差 $e$ 差異となる。従って、仮想地球の $\delta, \rho, e$ と実際の地球の それらとを同一視しても、そうすることによって生ずる実際の地球の $\delta, \rho, e$ の誤差は微細であることが分かる。

既述のような事情を考慮すると、実際の地球のある年の春分点や近 日点を「非常に」正確に予測することは困難であることが分かる。建 築的実用性からすれば、仮想地球に関して「適当に」決めた春分点や 近日点をもとにして求めた仮想地球の日赤緯。均時差。地球太陽間距 離が実際の地球に関しで十分に精確であれぱ、それらを用いていいの ではないかと考えられる。。本研究においては、2001 年の仮想地球の 近日点として表 2 に示与 3.27225 日（通日）を採用し、2001 年の仮 想地球の春分点として後述のように 79.56329 日（通日）を採用し、 それぞれを近点年及び兆陽年の周期の起点（基淮点）として採用する ことにした。どちらの值も、仮想地球の正確な近日点や春分点の值で あるとはい難いが、それぞれ、仮想地球の「近日点に極めて近い（具 体的には、近日点からの差異が 3.27225 の値に含まれる誤差に等し い) 近点年中の特定の時点」と「春分点に極めて近い（具体的には、 春分点からの差異が 79.56329 の値に含まれる誤差に等しい）太陽年 中の特定の時点」にはなっている。本研究においては、これらの特定 の時点をそれぞれ「代用近日点」「代用春分点」と呼ぶことにした。 


\section{3. 日赤緯 $\delta$}

日赤緯 $\delta$ は、太陽が天球の黄道上のどの点に位置するかによって決 まる。太陽が天球の黄道上を一周する周期は 1 太陽年 (365.24219 日) であるから、日赤緯 $\boldsymbol{\delta}$ ，変動周期もまた 1 太陽年である。従って、日 赤緯 $\delta$ の值は、太陽が黄道上の特定点（例えば春分点）を通過してか らの経過時間の関数として求めるのがよいと考えられる。

そこで、まず、1997 年から 2001 年までの 5 年間について、春分 の日をそれぞれ 30 日経過した日の日赤緯として理科年表に載ってい る値をピックアップし、相互の関係に注目してみた。表4にそれらの 値を示したが、一見すると、この表には $11^{\circ}$ よりも少し大きな值が 無秩序に並んでいるように見えるだけである。

\section{表 4 春分の日から 30 日目の日赤緯}

\begin{tabular}{|c|c|c|}
\hline 春分点(世赛寺) & 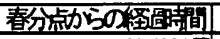 & 旦赤緯 \\
\hline 1997/3/20 13 時 5万分 & 294201 日 & $41^{\prime \prime}\left(11.1114^{\circ}\right.$ \\
\hline $1998 / 3 / 20$ & $29.1701 \mathrm{~B}$ & $\left(11.0258^{\circ}\right.$ \\
\hline $1999 / 3 / 21$ & 29.9264日 & $\left(11.2881^{\circ}\right.$ \\
\hline $2000 / 3 / 20$ & 296840 日 & $\left(112009^{\circ}\right)$ \\
\hline $2001 / 3 / 20 \quad 13$ 時 & 29.4368 日 & $5^{\prime \prime}\left(11.1181^{\circ}\right)$ \\
\hline
\end{tabular}

図 1 は、春分経過後 30 日目の日赤緯として理科年表に載っている 值を、太陽が春分点を通過してからの経過時間の関数として図示した ものである。

理科年表の值を書き移した表 4 だけを見ると、年によってかなり不 規則に見える変動が、図1を見ると、実は、春分点通過後の経過時間 に応じて整然と変動していることが分かる。このことからも、日赤緯 は、春分の日とか 1 月 0 日（前年の 12 月 31 日）とかからの整数で 表わした経過日数の関数としてではなく、太陽年中の特定の時点（例 えば春分点) からの経過時間の関数として求めることの妥当性が認め られる。

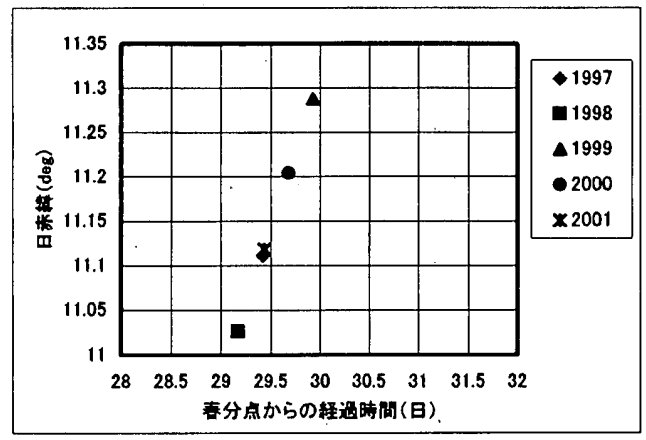

図 1 春分程過後 30 日目の日赤䋖

そこで、本研究では、日赤緯 $\delta(\mathrm{deg})$ を太陽の春分点通過後の経過 時間 $x$ (日)を変数とするフーリエ級数で近似することを試みた。

フーリエ級数の係数は、まず、周期を太陽年として、その周期を 96

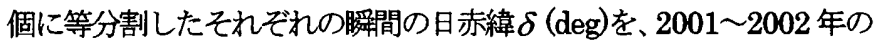
理科年表に示されているその瞬間の前後の4時点の值から補間で求め、
それらの值から調和解析の理論 ${ }^{3)}$ に基づいて求めた。この計算の過程 では、理科年表掲載の $\delta$ の值を仅想地球の $\delta$ の值と見なしている。

日赤緯 $\delta(\mathrm{deg})$ を次の関係式(2)で近似することにすれば、そこに現 れる俰数 $a_{m}(0 \leqq m \leqq 48)$ と $b_{m}(1 \leqq m \leqq 47)$ は、調和解析の理論によっ て、表5に示すように求められる。

$$
\begin{gathered}
\delta=a_{0}+\sum_{m=1}^{48} a_{m} \cos \left(\frac{2 m \pi}{365.24219} x\right)+\sum_{m=1}^{47} b_{m} \sin \left(\frac{2 m \pi}{365.24219} x\right) \\
\text { 表 } 5 \text { 式(2)の } a_{0} 、 a_{m} 、 b_{m} \text { の値 }
\end{gathered}
$$

\begin{tabular}{|l|r|r|r|r|r|}
\hline$a_{0}$ & 0.378154 & & & & \\
\hline$a_{1} \sim a_{5}$ & -0.753300 & 0.363669 & 0.019888 & -0.007529 & -0.000652 \\
\hline$a_{6} \sim a_{10}$ & 0.000269 & 0.000052 & 0.000017 & 0.000023 & 0.000028 \\
\hline$a_{11} \sim a_{15}$ & 0.000119 & -0.000073 & -0.000025 & 0.000028 & 0.000016 \\
\hline$a_{16} \sim a_{20}$ & 0.000022 & -0.000007 & 0.000008 & 0.000012 & 0.000008 \\
\hline$a_{21} \sim a_{25}$ & 0.000003 & 0.000025 & 0.000019 & 0.000010 & 0.000020 \\
\hline$a_{26} \sim a_{30}$ & 0.000019 & 0.000018 & 0.000014 & 0.000009 & 0.000010 \\
\hline$a_{31} \sim a_{35}$ & 0.000016 & 0.000030 & 0.000009 & 0.000022 & 0.000024 \\
\hline$a_{36} \sim a_{40}$ & 0.000026 & 0.000002 & 0.000018 & -0.000005 & 0.000014 \\
\hline$a_{41} \sim a_{45}$ & 0.000008 & 0.000009 & 0.000024 & 0.000005 & 0.000014 \\
\hline$a_{46} \sim a_{48}$ & -0.000006 & 0.000028 & 0.000008 & & \\
\hline$b_{1} \sim b_{5}$ & 23.250994 & 0.112605 & -0.170213 & -0.002986 & 0.003400 \\
\hline$b_{8} \sim b_{10}$ & 0.000155 & -0.000054 & 0.000055 & 0.000062 & 0.000116 \\
\hline$b_{11} \sim b_{15}$ & 0.000323 & -0.000096 & 0.000243 & -0.000218 & -0.000088 \\
\hline$b_{18} \sim b_{20}$ & -0.000053 & -0.000039 & -0.000045 & -0.000038 & -0.000033 \\
\hline$b_{21} \sim b_{25}$ & -0.000028 & -0.000024 & -0.000028 & -0.000005 & -0.000018 \\
\hline$b_{28} \sim b_{30}$ & -0.000008 & 0.000002 & -0.000008 & -0.000012 & -0.000013 \\
\hline$b_{31} \sim b_{35}$ & -0.000004 & 0.000005 & -0.000004 & 0.000003 & -0.000010 \\
\hline$b_{36} \sim b_{40}$ & -0.000004 & 0.000013 & -0.000007 & -0.000007 & -0.000005 \\
\hline$b_{41} \sim b_{45}$ & -0.000022 & -0.000012 & 0.000024 & -0.000010 & 0.000013 \\
\hline$b_{48} \sim b_{47}$ & -0.000002 & -0.000009 & - & - & \\
\hline
\end{tabular}

式(2)中の $x$ (日)としては春分点からの経過時間を採用するのがよ いと思われたが、春分点の正確な通日が不明であるため、式(3)で与 えられるもので代用することにした。ここに、通日とは世界時の 1 月 0 日 0 時からの経過時間を意味するものとする。

$$
x=\text { 通日一その年の代用春分点の通日 }
$$

式(2)の精度を調べるために、この式を用いて 2001 年の日赤緯 $\delta$ を求めてみたところ、表6のような值が得られた。この計算の過程で は 2001 年の代用春分点の通日として 79.56329 (日) を用いた。この 值は理科年表掲載の 1 日毎の $\delta$ の数表から補間で求めたものである が、これを日時分に換算して分の小数部分を四捨五入すると、春分点 として理科年表中の別表に特記されている表 1 の値と一致する。そこ で、本研究においては、正確な值は不明であるが、この值を仮想地球 の 2001 年の春分点として代用することにした。念のために言及する と、ここで採用した 2001 年の代用春分点の通日 79.56329 (日) を仮 想地球の真の春分点の通日と見なした場合の誤差がたとえかなり大 きかったとしても、前述のように、代用春分点は太陽年中の 1 つの特 定の時点となっていて、その特定の時点に基づいて表 5 の值が求めら れているので、代用春分点の真の春分点からの誤差が、式(2)，(4) 及ひ表 5から得られる $\delta$ の精度を損うことはない。表6から判断する と、この式(2)と表 5 から求められる $\delta$ の值は十分な精度を有すると 判断してよさそうである。 
表 6 日赤緯 $\delta$ の誤差の検討

\begin{tabular}{|c|c|c|c|c|c|c|c|}
\hline 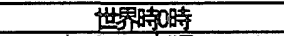 & \multicolumn{3}{|c|}{ 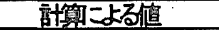 } & \multicolumn{3}{|c|}{ 理海表の傅 } & \\
\hline 2001年3月22日（通日81日) & 0 & 34 & $6^{\prime \prime}$ & & 34 & & $3^{\prime \prime}$ \\
\hline $\begin{array}{l}\text { 䏠20日 (通日171日) } \\
\end{array}$ & 23 & 25 & $57^{\prime \prime}$ & 23 & 25 & & 0 \\
\hline 2001年月月18日（通且261日) & 1 & 55 & $39^{\prime \prime}$ & 1 & 55 & 3 & $0^{\prime \prime}$ \\
\hline 2001年12月17日（通日351日） & -23 & 20 & $54^{n}$ & -23 & 20 & 5 & $0^{\prime \prime}$ \\
\hline
\end{tabular}

ここで、式(2)中の $a_{m} 、 b_{m}$ のうちで、值が小さい $a_{7} 、 b_{7}$ 以降を 省略すると、

$$
\begin{aligned}
& \delta=0.37815 \\
& -0.75330 \cos \left(\frac{2 \pi}{365.24219} x\right)+23.25099 \sin \left(\frac{2 \pi}{365.24219} x\right) \\
& +0.36367 \cos \left(\frac{4 \pi}{365.24219} x\right)+0.11261 \sin \left(\frac{4 \pi}{365.24219} x\right) \\
& +0.01989 \cos \left(\frac{6 \pi}{365.24219} x\right)-0.17021 \sin \left(\frac{6 \pi}{365.24219} x\right) \\
& -0.00753 \cos \left(\frac{8 \pi}{365.24219} x\right)-0.00299 \sin \left(\frac{8 \pi}{365.24219} x\right) \\
& -0.00065 \cos \left(\frac{10 \pi}{365.24219} x\right)+0.00340 \sin \left(\frac{10 \pi}{365.24219} x\right) \\
& +0.00027 \cos \left(\frac{12 \pi}{365.24219} x\right)+0.00016 \sin \left(\frac{12 \pi}{365.24219} x\right)
\end{aligned}
$$

\begin{tabular}{|c|c|c|c|c|c|c|}
\hline 世界時0時 & \multicolumn{2}{|c|}{ 㝇算こよる值 } & \multicolumn{3}{|c|}{ 理科年表の偩 } & 墔 \\
\hline 2001年3月22日(通日81日) & 0 & 34 & 0 & 34 & $3^{\prime \prime}$ & $2^{N}$ \\
\hline 2001年6月20日（通日171日） & 23 & $57^{\prime \prime}$ & 23 & $25^{\prime}$ & $57^{\prime \prime}$ & $0^{\prime \prime}$ \\
\hline 2001年9月18日(通日261日) & 1 & $39^{\prime \prime}$ & 1 & $55^{\prime}$ & $39^{\prime \prime}$ & $0^{\prime \prime}$ \\
\hline 2001年12月17日（通日351日） & -23 & $54^{\prime \prime}$ & -23 & $20^{2}$ & $54^{\prime \prime}$ & 0 \\
\hline
\end{tabular}

となり、この式(4)から日赤緯 $\delta$ を求めてみると表 7 のうになった。

\section{表 7 日赤緯 $\delta$ の詔差の検誩}

この $2 つ の$ 表から、項数の多い式(2)を用いても、項数の少ない式 （4)を用いても計算結果に殆ど差がないことが分かる。他の幾つかの 時点についても両式の計算結果を比較してみたが、実用上問題となる ような差は見られなかった。

従って、日赤緯 $\delta$ の関係式としては、式(4)でも十分であると思わ れる。

\section{4. 地球太陽間の距䴤 $\rho$}

地球太陽間の距離 $\rho$ は、地球が公転軌道上のどの点に存在するか によって決まり、天文単位 (AU) を単位として表示することが普通 である。仮想地球の公転軌道は太陽を焦点とする楕円形で、仮想地球 の公転周期は 1 近点年 (365.25964 日) であるから、 $\rho$ の変動周期も また 1 近点年である。従って、 $\rho$ は、仮想地球が地球公転軌道上の特 定点 (例えば近日点) を通過してからの経過時間の関数として求める のがよいと考えられる。

そこで、「2．太陽年と近点年について」において決定した代用近

\begin{tabular}{|c|c|c|c|c|c|}
\hline$a_{0}$ & 1.0001385 & & & & \\
\hline$a_{1} \sim a_{5}$ & -0.0166805 & -0.0001516 & -0.0000056 & -0.0000029 & -0.0000013 \\
\hline$a_{6} \sim a_{10}$ & -0.0000014 & -0.0000015 & -0.0000016 & -0.0000016 & -0.0000041 \\
\hline$a_{1} \sim a_{15}$ & -0.0000054 & -0.0000189 & 0.0000112 & 0.0000040 & 0.0000030 \\
\hline$a_{16} \sim a_{20}$ & 0.0000013 & 0.0000012 & 0.0000014 & 0.0000013 & 0.0000010 \\
\hline$a_{21} \sim a_{25}$ & 0.0000006 & 0.0000009 & 0.0000010 & 0.0000035 & -0.0000001 \\
\hline$a_{26} \sim a_{30}$ & 0.0000003 & 0.0000003 & 0.0000003 & 0.0000004 & 0.0000002 \\
\hline$\frac{a_{31} \sim a_{35}}{a_{1}}$ & 0.0000002 & 0.0000002 & 0.0000004 & 0.0000002 & 0.0000006 \\
\hline$a_{30} \sim a_{40}$ & 0.0000003 & 0.0000005 & -0.0000002 & 0.0000001 & 0.0000001 \\
\hline$a_{41} \sim a_{45}$ & 0.0000001 & 0.0000001 & 0.0000000 & 0.0000001 & 0.0000001 \\
\hline$a_{46} \sim a_{48}$ & 0.0000001 & -0.0000010 & 0.0000002 & & \\
\hline$b_{1} \sim b_{9}$ & 0.0000065 & 0.0000020 & -0.0000028 & -0.0000020 & -0.0000015 \\
\hline$b_{6} \sim b_{10}$ & -0.0000016 & -0.0000018 & -0.0000017 & -0.0000003 & -0.0000009 \\
\hline$b_{11} \sim b_{15}$ & -0.0000018 & -0.0000045 & 0.0000023 & 0.0000017 & 0.0000002 \\
\hline$b_{18} \sim b_{20}$ & 0.0000006 & -0.0000002 & 0.0000003 & 0.0000000 & 0.0000003 \\
\hline$b_{21} \sim b_{25}$ & 0.0000000 & 0.0000002 & -0.0000002 & -0.0000005 & 0.0000001 \\
\hline$b_{28} \sim b_{30}$ & 0.0000001 & 0.0000001 & 0.0000000 & 0.0000001 & 0.0000000 \\
\hline$b_{31} \sim b_{35}$ & 0.0000001 & -0.0000001 & 0.0000000 & 0.0000001 & 0.0000002 \\
\hline$b_{38} \sim b_{40}$ & 0.0000001 & -0.0000001 & 0.0000001 & 0.0000000 & 0.0000000 \\
\hline$b_{41} \sim b_{45}$ & -0.0000001 & 0.0000000 & 0.0000000 & 0.0000001 & 0.0000000 \\
\hline$b_{48} \sim b_{47}$ & 0.0000001 & 0.0000004 & & & \\
\hline
\end{tabular}
日点 (3.27225 日) を起点に、既述の $\delta$ にいてと同様な方法で、 $\rho$ のフーリエ級数による表示を試みると、式(5)と表 8 の倸数が得られ る。

$$
\rho=a_{0}+\sum_{m=1}^{48} a_{m t} \cos \left(\frac{2 m \pi}{365.25964} x\right)+\sum_{m=1}^{47} b_{m} \sin \left(\frac{2 m \pi}{365.25964} x\right) \cdot
$$

表8 式(5)の $a_{0} 、 a_{m} 、 b_{m}$ の値

式(5)中の $x$ (日)は式(6)で与えられる。ここで代用近日点を採用し ているのは、 $\delta$ を求める際に代用春分点を採用したのと同様の理由に よる。

$$
x=\text { 通日ーその)年の代用近日点の通日 }
$$

\begin{tabular}{|c|c|c|c|}
\hline 世界時0時 & 䯓算による徝 & 理科年表の值 & 差 \\
\hline 2001年3月22日（通自81日) & 0.99645 & 0.99645 & 0.00000 \\
\hline 2001年6月20日 (通巨171日) & 1.01618 & 1.01618 & 0.00000 \\
\hline 2001年9月18日（通比261日） & 1.00488 & 1.00488 & 0.00000 \\
\hline 2001年12月17日(通田351日) & 0.98412 & 0.98412 & 0.00000 \\
\hline
\end{tabular}

式(5)と表 8 から得られる $\rho$ の值の精度を 2001 年について既述と 同様な力法で調べてみると、関連する数值が表 9 のように得られた。 この表から、式(5)と表8から得られる $\rho$ の值は十分な精度を有する としてよさそうである。なお、式 6)中の代用春分点を仮想地球の真

\begin{tabular}{|c|c|c|c|}
\hline 世界時0時 & 触筮による偭 & 理科年㖵の值 & 蓓 \\
\hline 2001年3月22日 (通巨|81日) & 0.99642 & 0.99645 & -0.00003 \\
\hline 2001年6月20日（通E171日) & 1.01615 & 1.01618 & -0.00003 \\
\hline 2001年9月18日 (通E|261日) & 1.00485 & 1.00488 & -0.00003 \\
\hline 2001年12月17日（通四351日） & 0.98408 & 0.98412 & -0.00004 \\
\hline
\end{tabular}
の近日点と見なしたときにその誤差がたとえ大きかったとしても、そ のことが式(5)と表 8 から得られる $\rho$ の值の精度を損うことにはな らないことはいうまでもない。

\section{表 9 地球太陽間距離 $\rho$ の誤差}

また、その式の $a_{7} 、 b_{7}$ 以降の係数をすべて 0 としても十分な精度 を保つことも分かる（婊 10 参照)。

表 10 地球太晹間距離 $\rho$ (誤差 $\left(a_{7} 、 b_{7}\right.$ 以降の係数をすべて 0 とした場合)

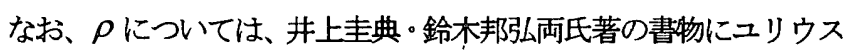
日を独立変数とする優れた略算式 ${ }^{4)}$ が紹介されているが、ここでは詳 述しない。 


\section{5. 均時差 $e$}

均時差eは、地球が公転軌道上を動く速さの影響を強く受けるので、 地球太陽間の距離 $\rho$ と同様に、周期を 1 近点年として、地球が公転軌 道上の特定点（例えば近日点）を通過してからの経過時間 $x$ (日)の関 数として表示することがよさそうである。

そこで均時差 $e$ を、前項で求めた 2001 年の近日点 (3.27225) を起 点に、周期を近点年として、 $\delta$ や $\rho$ にいてと同様な方法でフーリ エ級数によって表示することを試みた。

均時差 $e$ を次の関係式 (7)で近似することにすれば、そこに現れる 係数 $a_{m}(0 \leqq m \leqq 48)$ と $b_{m}(1 \leqq m \leqq 47)$ は、調和解析の理論によって、 表 11 に示すように求められる。

$$
e=a_{0}+\sum_{m=1}^{48} a_{m} \cos \left(\frac{2 m \pi}{365.25964} x\right)+\sum_{m=1}^{47} b_{m} \sin \left(\frac{2 m \pi}{365.25964} x\right)
$$

表 11 式(7)の $a_{0} 、 a_{m} 、 b_{m}$ の値

\begin{tabular}{|l|r|r|r|r|r|}
\hline$a_{0}$ & 0.00938 & & & & \\
\hline$a_{1} \sim a_{5}$ & 0.14172 & -4.30575 & -0.13205 & -0.16984 & -0.01038 \\
\hline$a_{8} \sim a_{10}$ & -0.00626 & -0.00045 & -0.00015 & -0.00007 & -0.00020 \\
\hline$a_{11} \sim a_{15}$ & -0.00007 & -0.00102 & 0.00072 & 0.00034 & 0.00028 \\
\hline$a_{16} \sim a_{20}$ & 0.00010 & 0.00021 & 0.00012 & 0.00008 & 0.00016 \\
\hline$a_{21} \sim a_{25}$ & 0.00003 & 0.00011 & 0.00011 & 0.00004 & -0.00002 \\
\hline$a_{26} \sim a_{30}$ & 0.00022 & 0.00020 & 0.00003 & 0.00023 & 0.00019 \\
\hline$a_{31} \sim a_{35}$ & 0.00020 & 0.00013 & 0.00016 & 0.00008 & 0.00008 \\
\hline$a_{36} \sim a_{40}$ & 0.00010 & 0.00010 & 0.00007 & -0.00007 & 0.00017 \\
\hline$a_{41} \sim a_{45}$ & 0.00019 & 0.00021 & 0.00021 & 0.00007 & 0.00002 \\
\hline$a_{40} \sim a_{48}$ & 0.00013 & 0.00008 & 0.00008 & & \\
\hline$b_{1} \sim b_{5}$ & -7.35058 & -8.94384 & -0.28744 & -0.13790 & -0.00822 \\
\hline$b_{6} \sim b_{10}$ & -0.00100 & 0.00049 & 0.00073 & 0.00088 & 0.00109 \\
\hline$b_{11} \sim b_{15}$ & 0.00161 & 0.00560 & -0.00314 & -0.00095 & -0.00087 \\
\hline$b_{18} \sim b_{20}$ & -0.00051 & -0.00050 & -0.00034 & -0.00030 & -0.00023 \\
\hline$b_{21} \sim b_{25}$ & -0.00019 & -0.00020 & -0.00029 & -0.00017 & -0.00007 \\
\hline$b_{28} \sim b_{30}$ & -0.00016 & -0.00011 & -0.00004 & 0.00001 & -0.00007 \\
\hline$b_{31} \sim b_{35}$ & -0.00005 & -0.00018 & -0.00005 & -0.00010 & -0.00015 \\
\hline$b_{36} \sim b_{40}$ & -0.00006 & -0.00010 & 0.00007 & -0.00002 & 0.00004 \\
\hline$b_{41} \sim b_{45}$ & -0.00007 & 0.00002 & -0.00003 & 0.00013 & -0.00009 \\
\hline$b_{46} \sim b_{47}$ & 0.00009 & 0.00003 & - & - & \\
\hline
\end{tabular}

式中の $x($ 日)には式(8)から得られる值を用いる。

$$
x=\text { 通日ーその年の代用近日点の通日 }
$$

式(7)の精度を上述と同様の方法で2001年について調べてみると、 関連する数值が表 12 のように得られた。

\begin{tabular}{|c|c|c|c|c|}
\hline 世界時0時 & 計算による值 & 理科年表の陋 & & 差 \\
\hline 2001年3月22日（通日81日） & $-6 \mathrm{~m} 59.3 \mathrm{~s}$ & $-6 \mathrm{~m} \quad 59.4$ & & $0.1 \mathrm{~s}$ \\
\hline 2001年6月20日 (通日171日) & $-1 \mathrm{~m}$ & $-1 \mathrm{~m}$ & s & 0.0 \\
\hline 2001年9月18日（通日261日） & 43.3 & 43.3 & $s$ & 0.0 \\
\hline 2001年12月17日(通日351日) & $4.6 \mathrm{~s}$ & $4 \mathrm{~m}$ & s & $0.0 \mathrm{~s}$ \\
\hline
\end{tabular}

\section{表 12 均時差 $e$ の誤差}

また、式(7)中の $a_{7} 、 b_{7}$ 以降の係数をすべて 0 として均時差 $e$ を 求めてみると表 13 のようになった。

表 13 均時差 $e$ の䛊差（ $a_{7} 、 b_{7}$ 以降の係数をすべて 0 とした場合）

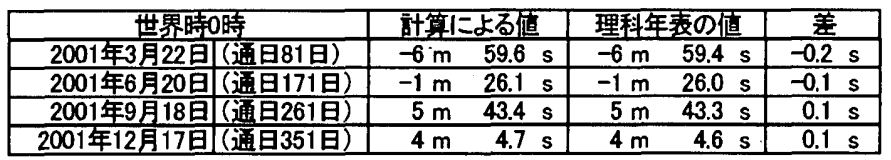

この 2 つの表から、項数の多い式 $(7)$ を用いても、 $a_{7} 、 b_{7}$ 以降を 省略して項数を诚らしても、計算結果に殆ど差がないことが分かる。 他の幾つかの時点についても両式の計算結果を比較してみたが、実用 上問題となるような差は見られなかった。従って、均時差e の関係式 としては、式(7)の $a_{7} 、 b_{7}$ 以降を省略しても精度は十分に保てると 思われる。

\section{6. 未来の $\delta, \rho, e$ の推測とまとめ}

日赤緯の計算式においては仮想地球の代用春分点を起点とし、地球 太陽間距離と均時差の計算式においては仮想地球の代用近日点を起 点としたが、仮想地球の未来の代用春分点、代用近日点を求めること は 2001 年の代用春分点、代用近日点にそれぞれ太陽年、近点年の何 倍かを加算すれば求めることができるので、この論文で述べられてい る計算式を用いれば未来の日赤緯、地球太陽間距離、均時差の予測が 十分な精度をもって可能であると考えられる。

本研究で採用した 2001 年の代用春分点、代用近日点を起点に、太 陽年（365.24219 日）、近点年（365.25964 日）を加算して、末来の 代用春分点、代用近日点を予测すると、表 $14 、 15$ のような值が得ら れる。

\begin{tabular}{|c|c|c|c|c|c|c|}
\hline & 通日 & \multicolumn{5}{|c|}{ 曆 } \\
\hline 001年 & 79.56329 & 3月 & 20日 & 13 時 & 31 分 & 8 \\
\hline 02年 & .80548 & 3 月 & 20 日 & 19 時 & 19 分 & 54 秒 \\
\hline 3年 & 04767 & 3月 & 21 日 & 1 時 & 8 分 & 39 秒 \\
\hline & 80.28986 日 & 3 月 & 20 日 & 6 時 & 57 分 & 24 秒 \\
\hline 05年 & 79.53205 日 & 3 月 & 20 日 & 12 時 & 46 分 & 9 秒 \\
\hline 军 & 79.77424 日 & 3月 & 20 日 & 18 時 & 34 分 & 55 秒 \\
\hline & .01643 & 3月 & 21 日 & 0 時 & 23 分 & 40 秒 \\
\hline & 80.25862 & 3 月 & 20 日 & 6 時 & 12 分 & 25 秒 \\
\hline & 79.5 & 3 月 & 20 日 & 12 時 & 13 & 10 和 \\
\hline & 79.7 & 3月 & 20 日 & 17 時 & 49 分 & 55 \\
\hline & 79.98519 & 3月 & 20 日 & 23 時 & 38 分 & 41 秒 \\
\hline
\end{tabular}

\section{表 14 仮想地球の未来の代用春分点}

\begin{tabular}{|c|c|c|c|c|c|c|}
\hline & 通日 & \multicolumn{5}{|c|}{ 暦 } \\
\hline 2001年 & 3.27225 日 & 1月 & 3 日 & 6 時 & 32 分 & 2 秒 \\
\hline 2002年 & 3.53189 日 & 1月 & 3 日 & 12 時 & 45 分 & 55 秒 \\
\hline 2003年 & 3.79153 日 & 1月 & 3 日 & 18 時 & 59 分 & 48 秒 \\
\hline 2004年 & 4.05117 日 & 1月 & 4 日 & 1 時 & 13 分 & 41 秒 \\
\hline 2005年 & 3.31081 日 & 1月 & 3 日 & 7 時 & 27 分 & 34 秒 \\
\hline 2006年 & 3.57045 & 1月 & 3 日 & 13 時 & 41 分 & 27 秒 \\
\hline 2007年 & 3.83009 & 1月 & 3 日 & 19 時 & 55 分 & 20 秒 \\
\hline 2008年 & 4.08973 & 1月 & 4 日 & 2 時 & 9 分 & 12 秒 \\
\hline 2009年 & 3.34937 日 & 1月 & 3 日 & 8 時 & 23 分 & 5 秒 \\
\hline 2010年 & 3.60901 & 1月 & 3 日 & 14 時 & 36 分 & 58 秒 \\
\hline 2011年 & 3.86865 & 1月 & 3 日 & 20 時 & 50 分 & 51 秒 \\
\hline
\end{tabular}

表 15 仮想地球の未来の代用近日点

表 14，15に示寸予測值は仮想地球に関するものであるから、それ らと実際の地球の春分点や近日点との間には、表 1 ，表 3 から判断す ると、最大では、春分点で 5 分程度、近日点では 5 時間程度の時間的 な差異が生ずることが分かる。これらの差異は自然現象として生ずる ものであって、仮想地球の春分点や近日点の推定值とそれらの真の值 との間の誤差ではない。れらの差異によって実際の地球の $\delta, \rho$ ， 
$e$ に反映される誤差は、それらの年間変動の様子から判断して、 $\delta$ で5" 以下、 $\rho$ で 0.00006 (AU) 以下、 $e$ で $6(\mathrm{~s})$ 以下と考えられ る。

また、念のため、本研究で得られた $\delta, \rho, e$ の近似計算式の精 度を過去の 1991，1994，1997年について調べてみたところ、それぞ れ、表 16、17、18のような值が得られた。なお、ここで使用した代 用春分点、代用近日点は本研究で採用した 2001 年の代用春分点、代 用近日点からそれぞれ当該太陽年、近点年さかのぼったものである。

表6、9、12、16、17、18 などに示されている值や、「2. 太陽 年と近点年について」で述べている仮想地球の $\delta, \rho, e$ と実際の地 球のそれらとの間の差異、並びここの直前で述へててい仮想地球の代 用春分点及び代用近日点と実際の地球の春分点及び近日点との間の 差異によって生ずる $\delta, \rho, e$ の誤差などから判断して、これらの式 は未来の值の推測に関しても実用に耐える精度を有するものとして よさそうである。本研究で得られた $\delta, \rho, e$ 近似式から得られる 值の誤差は、概ね、 $\delta$ では 30" 以下、 $\rho$ では0.0001 (AU) 以下、 $e$ では 6 （s）以下と考えてよさそうである。

\section{表 $16 \delta$ の式の精度の検討}

\begin{tabular}{|c|c|c|c|c|c|c|}
\hline 世界時榯 & \multicolumn{2}{|c|}{ 针算こよる值 } & \multicolumn{3}{|c|}{ 理涹年表の顛 } & 管 \\
\hline 1991年3月25日 (通日84日) & $11^{\circ} \cdot 31^{\prime}$ & $211^{\prime \prime}$ & $11^{\circ}$ & $311^{\prime}$ & $42^{\prime \prime}$ & $-21 . "$ \\
\hline 1991年6月13 (通日174日) & $23^{\circ} 26^{\prime}$ & 4 !" & $231^{\circ}$ & 26 ! $^{\prime}$ & $13^{\prime \prime}$ & $-9^{\prime \prime}$ \\
\hline 1991年9月21日(通日264日) & $0^{\circ} 59^{\prime}$ & $17]^{\prime \prime}$ & $00^{\circ}$ & $59 !^{\prime}$ & $7^{\prime \prime}$ & $10^{\prime \prime}$ \\
\hline 1991年12月20日 (通日354日) & $-23^{\circ} \cdot 25^{\prime}$ & $0.3^{\prime \prime}$ & $-23^{\circ}$ & $25 !^{\prime}$ & $7^{\prime \prime}$ & $7^{\prime \prime}$ \\
\hline 1994年3月19日（通日78日） & $-0^{\circ} \cdot 44^{\prime}$ & $15 "$ & $-0^{\circ}$ & $43 !^{\prime}$ & 57 " & $-18 . "$ \\
\hline 1994年6月17日(通旦168日) & $23 !^{\circ} 21^{\prime}$ & $53\}^{\prime \prime}$ & $233^{\circ}$ & $21 !^{\prime}$ & $53]^{\prime \prime}$ & $0^{\prime \prime}$ \\
\hline 1994年9月15日（通日258日） & $3^{\circ} 12^{\prime}$ & $9.9^{\prime \prime}$ & $3 i^{\circ}$ & 11 & 59 " & $11^{\prime \prime}$ \\
\hline 1994年12月14日（通日348日） & $-23^{0 \cdot} \cdot 10^{\prime}$ & $54^{\prime \prime}$ & $-\left.23\right|^{\circ}$ & $10^{\prime}$ & $54^{\prime \prime}$ & $0^{\prime \prime}$ \\
\hline 23日（通日82 & $0^{\circ} 57^{\prime}$ & $1.1^{\prime \prime}$ & $0^{\circ}$ & 57 ! & 19 " & $-18 . "$ \\
\hline 1997年月21日(通日172日) & $23^{\circ} 26^{\prime}$ & $\left.17\right|^{\prime \prime}$ & $231^{\circ}$ & 26 : & $12^{\prime \prime}$ & $5^{\prime \prime}$ \\
\hline 1997 9月19日 (通日262日) & $1^{\circ} 33^{\prime}$ & $7.7^{\prime \prime}$ & $1^{\circ}$ & 33 & $10 "$ & $-2^{\prime \prime}$ \\
\hline 1997年12月18日（通日352日） & $-23^{\circ} 22^{\prime}$ & $52^{\prime \prime}$ & $-23^{\circ}$ & 22 ' & 46 " & $-6^{\prime \prime \prime}$ \\
\hline
\end{tabular}

表 $17 \rho$ の式の精度の検討

\begin{tabular}{|c|c|c|c|}
\hline 世界時0墽 & 针算二よる面 & 理科年表の值 & 蕫 \\
\hline 1991年3月25日（濐回84日） & 0.99718 & 0.99711 & 0,00007 \\
\hline 1991年6月23日（速日174日） & 1.01634 & 1.01631 & 0.00003 \\
\hline 1991年9月21日（通日264日） & 1.00416 & 1.00412 & 0.00004 \\
\hline 1991年12月20日 (通日354日) & 0.98389 & 0.98383 & 0.00006 \\
\hline 1994年3月19日（通日78日） & 0.99554 & 0.99554 & 0.00000 \\
\hline 1994年6月17日(通日168日) & 1.01592 & 1.01592 & 0.00000 \\
\hline 1994年9月15日（通日258日） & 1.00573 & 1.00569 & 0.00004 \\
\hline 1994年12月14日（通日348日） & 0.98442 & 0.98434 & 0.00008 \\
\hline 1997年3月23日(遥日82日) & 0.99674 & 0.99667 & 0.00007 \\
\hline 1997年6月21日(通日172日) & 1.01625 & 1.01624 & 0.00001 \\
\hline 1997年9月19日（通日262日） & 1.00459 & 1.00454 & 0.00005 \\
\hline 1997年12月18日（福日352日) & 0.98402 & 0.98396 & 0.00006 \\
\hline
\end{tabular}

斐 $18 e$ の式の精度の檢討

\begin{tabular}{|c|c|c|c|c|c|c|c|}
\hline 世界时0時 & \multicolumn{3}{|c|}{ 撸算二よる值 } & \multicolumn{2}{|c|}{ 理科年表の值 } & 器 & \\
\hline 1991年3月25日 (通日84日) & $-6 / m$ & 12.6 & is & $-6 m$ & $16.8 \mathrm{~s}$ & 42 & \\
\hline 1991年6月23日（通日174日） & $-2 m$ & 0.2 & s & $-1 \mathrm{~m}$ & $57.6: \mathrm{s}$ & -2.6 & s \\
\hline 1991年9月21日（通日264日） & $6 / \mathrm{m}$ & 38.5 & Is & $6 \mathrm{~m}$ & \begin{tabular}{l:l} 
& \\
\hdashline 5.3 & $\mathrm{~s}$
\end{tabular} & 3.2 & $\mathrm{~s}$ \\
\hline 1991年12月20日 (通日354日) & $2 \mathrm{~m}$ & 47.8 & s & $2 m$ & $51.0 \mathrm{~s}$ & -3.2 & $\mathrm{~s}$ \\
\hline 1994年3月19日（通日78日） & $-7 \mathrm{~m}$ & 55.8 & Is & $-7 m$ & $59.4 \mathrm{~s}$ & 3.6 & s \\
\hline 1994年6月17日(通日168日) & $-0 \mid m$ & 44.2 & s & $-0 \mathrm{~m}$ & $43.0 \mathrm{~s}$ & -1.2 & $\mathrm{~s}$ \\
\hline 1994年9月15日（通日25\&日） & $4 m$ & 35.5 & Is & $4 m$ & $33.1 \mathrm{~s}$ & 2.4 & $\mathrm{~s}$ \\
\hline 1994年12月14日（通日348日） & $5 / \mathrm{m}$ & 36.9 & $s$ & $5 \mathrm{~m}$ & $37.8 \mathrm{~s}$ & -0.9 & s \\
\hline 1997年3月23日 $($ 鯂日82是) & $-6 / \mathrm{m}$ & 40.7 & s & $-6 m$ & $43.8 \mathrm{~s}$ & 3.1 & s \\
\hline 1997年6月21日(通日17'目) & $-1 \mathrm{~m}$ & 39.7 & s & $-1 m$ & $38.4 \mathrm{~s}$ & -1.3 & $\mathrm{~s}$ \\
\hline 1997年9月19日 (通日26分日) & $6] \mathrm{m}$ & 5.4 & $s$ & $6 \mathrm{~m}$ & $5.4 \mathrm{~s}$ & 0.0 & $\mathrm{~s}$ \\
\hline 1997年12月18日（邀日35：日） & $3 m$ & 34.0 & s & $3 \mathrm{~m}$ & \begin{tabular}{l:l} 
& \\
\hdashline 36.6 & $\mathrm{~s}$ \\
\end{tabular} & -2.6 & $s$ \\
\hline
\end{tabular}

\section{【参考文献】}

1）例えぼ、山崎均：日照貫境のための基整計算式, 日本建築学会論文坪告墨 No. 288, pp.139-147, 1980.2

2）国立天文台 : 理科年表、丸善，1990 2001

3）本間仁、窨日屋伸昌 : 次元解析・最小 2 乗法と苦䀦式, コロナ社, 1957

4）井上圭典、鈴木邦弘：天体位䲔略算式の解説, 海文堂, 1991 